\title{
Detecção de Cepas Virulentas de Arcobacter Butzleri em Carnes de Frangos e Suínos Provenientes de Açougues no Município de São Paulo
}

\author{
Maria Gabriela Xavier de Oliveira $(\mathrm{I}, \mathrm{I}, \mathrm{I}, \mathrm{I})$, Andrea Micke Moreno (I), \\ Maria Garcia Spindola (I), Vasco Túlio de Moura Gomes (I), Pedro \\ Henrique de Lima Filsner (I), Thaís Sebastiana Porfida Ferreira (I), \\ Terezinha Knöbl (I) \\ (I) FMVZ-USP - Faculdade de Medicina Veterinária e Zootecnia-USP (Av. Prof. Dr. Orlando \\ Marques de Paiva, 87 Cidade Universitária CEP 05508 270)
}

\section{Resumo}

A presença de patógenos zoonóticos em alimentos de origem animal é uma preocupação de saúde pública. O Arcobacter spp. é um micro-organismo Gram-negativo causador de diarreia aquosa e sepse em humanos; e a espécie A. butzleri é a de maior interesse na relação humano-animal. $\mathrm{O}$ objetivo do presente estudo foi detectar a presença de A. butzleri em carnes de frango e de suínos provenientes de açougues do Município de São Paulo, verificando os fatores de virulência associados à adesão (cadF e ciaB) e a invasão (cj 1349) deste agente. Um total de 115 cortes de carne de suínos e 105 de carne de frangos foram utilizados para cultivo e isolamento em caldo e ágar JM em condições de aerofilia, a $30^{\circ} \mathrm{C}$ por $72 \mathrm{~h}$.

Selecionaram-se as colônias características de Arcobacter, que foram submetidas à detecção molecular pela reação em cadeia da polimerase (PCR), para determinação da espécie e dos fatores de virulência. Constatou a presença de A. butzleri em 10,4\% (12/115) de amostras de carne de suínos e 4,7\% (5/105) de carne de aves. A pesquisa dos fatores de virulência demonstrou que $100 \%$ dos isolados foram positivos para os fatores de virulência cadF, ciaB e cj 1349. Apesar da virulência de Arcobacter spp. ser pouco elucidada, a capacidade de adesão e invasão são consideradas fundamentais na patogenicidade do agente. Os genes

\footnotetext{
Referência:

Maria Gabriela Xavier de Oliveira, Andrea Micke Moreno, Maria Garcia Spindola, Vasco Túlio de Moura Gomes, Pedro Henrique de Lima Filsner, Thaís Sebastiana Porfida Ferreira, Terezinha Knöbl. Detecção de Cepas Virulentas de Arcobacter Butzleri em Carnes de Frangos e Suínos Provenientes de Açougues no Município de São Paulo. In: Anais do $12^{\circ}$ Congresso Latinoamericano de Microbiologia e Higiene de Alimentos - MICROAL 2014 [= Blucher Food Science Proceedings, num.1, vol.1]. São Paulo: Editora Blucher, 2014. DOI $10.5151 /$ foodsci-microal-172
} 
pesquisados neste estudo estão associados a fatores encontrados em cepas provenientes de humanos de diversas origens do mundo, descritos por outros autores, elevando a importância do seu caráter zoonótico. Verificouse nesta pesquisa a presença de Arcobacter butzleri na fase final de comercialização de carnes de frangos e suínos em açougues. A falta de inocuidade de alimentos cárneos é motivo de preocupação, pois apesar de Arcobacter possuir propriedades de fácil eliminação a $55^{\circ} \mathrm{C}$, existe o risco de contaminação cruzada com outros produtos alimentares não cozidos e utensílios. Novos estudos de detecção de outros genes de virulência e da caracterização genotípica dos isolados serão realizados, com a finalidade de complementar as evidencias obtidas neste estudo.

Palavras-Chave: Arcobacter, carnes, zoonose, aves, suínos Agência de Fomento: Fapesp 